\title{
SEM-EDAX analysis of the Soil Samples of River Yamuna in Delhi Region
}

\author{
Vivek Chopra* and Jai Gopal Sharma**† \\ *Department of Botany, Hindu College, University of Delhi, Delhi-110007 India \\ **Department of Biotechnology, Delhi Technological University, Delhi-110042, India \\ $†$ Corresponding author: Jai Gopal Sharma; sharmajaigopal@ gmail.com
}

Nat. Env. \& Poll. Tech. Website: www.neptjournal.com

Received: 24-03-2020

Revised: $27-04-2020$

Accepted: $27-05-2020$

Key Words:

SEM-EDAX

River Yamuna

Soil analysis

Niobium

Aluminium

\begin{abstract}
A total of 18 samples were collected from two different sites at different depths of Yamuna river bed in Delhi. Nine samples were collected at Site A (Palla Village) from three different locations at different depths of the river bed. A similar set of 9 samples were collected from Site B (Okhla barrage). All samples were analysed for atomic and weight percentage of elements using SEM-EDAX. The major elements found in the study were $\mathrm{Si}, \mathrm{O}, \mathrm{Al}$ and $\mathrm{Nb}$. Si and $\mathrm{O}$ are found in a maximum amount in all the samples with a varying range of atomic percentage 25.3-89.27 and 55.09-95.78 respectively. The recorded atomic percentage of $\mathrm{Nb}$ was 0.32 while $\mathrm{Al}$ was $16.7-25.51$. Site A, Palla is least affected by pollution while at Site $\mathrm{B}$ the presence of $\mathrm{Al}$ revealed contamination from pollutants. The weight percentage of the elements has also been calculated. SEM images of soil samples revealed the platy flakes, irregular and spongy structure of soil particles.
\end{abstract}

\section{INTRODUCTION}

The River Yamuna is the longest and second largest tributary of river Ganga. Originating from the Yamunotri glaciers at a height of 6,387 $\mathrm{M}$ on the uppermost region of the lower Himalayas in Uttarakhand. Its $48 \mathrm{~km}$ stretch which passes from Delhi is a major source of drinking and potable water for the $70 \%$ population of Delhi (CPCB 2006). It shows the importance of river Yamuna as a major source of water and an indispensable part of the ecosystem. Many studies explain about the water quality of the river but hardly any are available about soil elemental composition. The present study reveals the atomic and weight percentage of different elements as well as some physical properties of soil samples collected from different depths of the river bed. The important elements observed in the following study are Silica (Si), Oxygen (O), Aluminium ( $\mathrm{Al}$ ) and Niobium ( $\mathrm{Nb}$ ). The aim of the study is to reveal the concentration of the elements at different depths of the river bed using SEM-EDAX techniques to enhance our knowledge about the physicochemical nature of the alluvial deposits in the river bed.

\section{MATERIALS AND METHODS}

A total of 18 samples were collected from two different sites (Fig. 1) of river Yamuna in March 2019. Site A

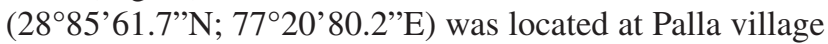
which is the point where River Yamuna enters in Delhi. Site

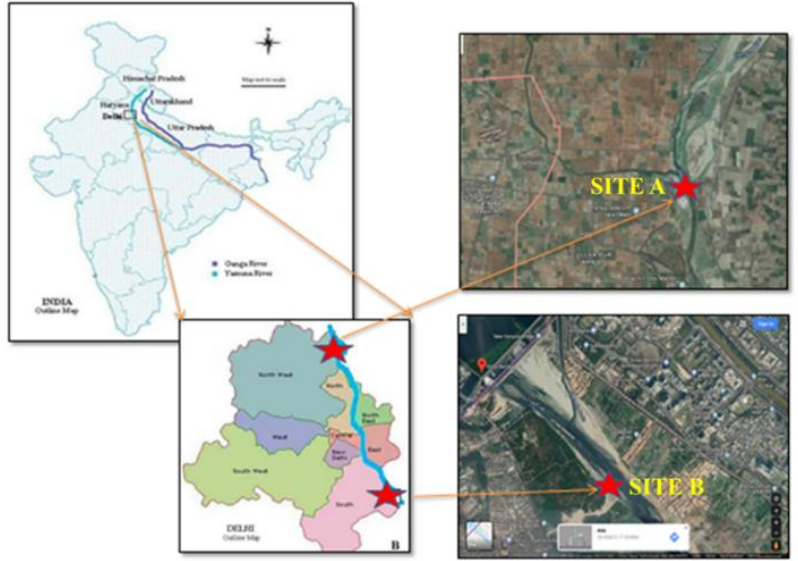

Fig. 1: Location of Site A (Palla village) and Site B (Okhla barrage) in Delhi.

A is comparatively free from pollutants and other anthropogenic activities beside agriculture in the vicinity. Multiple samples were collected to yield a better and authentic interpretation of results. Nine samples were collected from 3 different locations of Site A.

At location 1, the samples were taken from the surface $(0-2 \mathrm{~cm})$ and at the depth of $30-32 \mathrm{~cm}$ and $78-80 \mathrm{~cm}$ of the river bed. From location 2 and location 3, samples were taken from the surface $(0-2 \mathrm{~cm}), 30-32 \mathrm{~cm}$ and $74-76 \mathrm{~cm}$ and $0-2 \mathrm{~cm}, 26-28 \mathrm{~cm}$ and $59-61 \mathrm{~cm}$ respectively. The 
same set of sampling was done at Site B, i.e. Okhla barrage $\left(28^{\circ} 32^{\prime} 10.5^{\prime \prime} \mathrm{N}, 77^{\circ} 19^{\prime} 29.6\right.$ 'E) with 9 samples in total from three different locations at the surface $(0-2 \mathrm{~cm})$ and at various depths of 30-32 $\mathrm{cm}$ and $96-98 \mathrm{~cm}$ from location 4 and from location 5 and 6 at the surface $(0-2 \mathrm{~cm}), 30-32 \mathrm{~cm}$ and $62-$ $64 \mathrm{~cm}$ and $0-2 \mathrm{~cm}, 30-32 \mathrm{~cm}$ and $62-64 \mathrm{~cm}$ respectively. Site B is one of the most polluted stretches of river Yamuna where it receives a heavy load of industrial effluents and household sewage discharge from many major drains. Geographical locations were taken by Garmin GPSMAP 76 CSX global positioning system. Five- $10 \mathrm{mg}$ subsamples were homogenized, sun-dried and sieved out to remove excess unwanted debris, later the samples were dried in an oven at $60^{\circ} \mathrm{C}$ for three days to remove moisture completely (Das \& Mondal 2011, Tan 2005). Dried samples were mounted and microstructure was analysed using Scanning Electron Microscope model Zeiss EVO 18 research. The elemental composition was determined by an Energy Dispersive X-ray Spectroscopy (EDAX) attached to SEM.

\section{RESULTS AND DISCUSSION}

In all the 18 samples, EDAX analysis was performed to study the elements present in the soil. $\mathrm{Si}, \mathrm{O}, \mathrm{Nb}$, and $\mathrm{Al}$

Table 1: Elements Atomic \% of three locations at Site A (Palla Village).

\begin{tabular}{|c|c|c|c|c|c|c|c|c|c|}
\hline \multirow[t]{3}{*}{ Elements } & \multicolumn{3}{|c|}{ Depths at Location 1} & \multicolumn{3}{|c|}{ Depths at Location 2} & \multicolumn{3}{|c|}{ Depths at Location 3} \\
\hline & $0-2 \mathrm{~cm}$ & $30-32 \mathrm{~cm}$ & $78-80 \mathrm{~cm}$ & $0-2 \mathrm{~cm}$ & $30-32 \mathrm{~cm}$ & $74-76 \mathrm{~cm}$ & $0-2 \mathrm{~cm}$ & $26-28 \mathrm{~cm}$ & $59-61 \mathrm{~cm}$ \\
\hline & \multicolumn{9}{|c|}{ Atomic $\%$} \\
\hline Oxygen $(\mathrm{O})$ & 57.78 & 0 & 55.09 & 0 & 58.92 & 95.35 & 0 & 0 & 91.84 \\
\hline Silicon $(\mathrm{Si})$ & 36.78 & 83.85 & 38.69 & 89.27 & 35.49 & 0 & 79.82 & 81.94 & 0 \\
\hline Niobium (Nb) & 0.32 & 0 & 0 & 0 & 0 & 0 & 0 & 0 & 0 \\
\hline Aluminium (Al) & 0 & 0 & 0 & 0 & 0 & 0 & 0 & 0 & 0 \\
\hline
\end{tabular}

Table 2: Elements Weight \% of three locations at Site A (Palla Village).

\begin{tabular}{|c|c|c|c|c|c|c|c|c|c|}
\hline \multirow[t]{3}{*}{ Elements } & \multicolumn{3}{|c|}{ Depths at Location 1} & \multicolumn{3}{|c|}{ Depths at Location 2} & \multicolumn{3}{|c|}{ Depths at Location 3} \\
\hline & $0-2 \mathrm{~cm}$ & $30-32 \mathrm{~cm}$ & $78-80 \mathrm{~cm}$ & $0-2 \mathrm{~cm}$ & $30-32 \mathrm{~cm}$ & $74-76 \mathrm{~cm}$ & $0-2 \mathrm{~cm}$ & $26-28 \mathrm{~cm}$ & $59-61 \mathrm{~cm}$ \\
\hline & \multicolumn{9}{|c|}{ Weight $\%$} \\
\hline Oxygen $(\mathrm{O})$ & 30.86 & 27.6 & 0 & 0 & 31.01 & 62.51 & 0 & 0 & 47.76 \\
\hline Silicon $(\mathrm{Si})$ & 34.48 & 34.03 & 42.54 & 54.26 & 32.79 & 0 & 36.06 & 39.28 & 0 \\
\hline Niobium (Nb) & 0.98 & 0 & 0 & 0 & 0 & 0 & 0 & 0 & 0 \\
\hline Aluminium (Al) & 0 & 0 & 0 & 0 & 0 & 0 & 0 & 0 & 0 \\
\hline
\end{tabular}

Table 3: Elements Atomic \% of three locations at Site B (Okhla barrage).

\begin{tabular}{|c|c|c|c|c|c|c|c|c|c|}
\hline \multirow[t]{3}{*}{ Elements } & \multicolumn{3}{|c|}{ Depths at Location 4} & \multicolumn{3}{|c|}{ Depths at Location 5} & \multicolumn{3}{|c|}{ Depths at Location 6} \\
\hline & $0-2 \mathrm{~cm}$ & $30-32 \mathrm{~cm}$ & $76-98 \mathrm{~cm}$ & $0-2 \mathrm{~cm}$ & $30-32 \mathrm{~cm}$ & $67-69 \mathrm{~cm}$ & $0-2 \mathrm{~cm}$ & $26-28 \mathrm{~cm}$ & $62-64 \mathrm{~cm}$ \\
\hline & \multicolumn{9}{|c|}{ Atomic \% } \\
\hline Oxygen $(\mathrm{O})$ & 86.66 & 92.36 & 0 & 62.31 & 0 & 92.2 & 95.78 & 94.43 & 56.2 \\
\hline Silicon $(\mathrm{Si})$ & 0 & 0 & 81.67 & 31.75 & 60.17 & 0 & 0 & 0 & 25.3 \\
\hline Niobium (Nb) & 0 & 0 & 0 & 0 & 0 & 0 & 0 & 0 & 0 \\
\hline Aluminium (Al) & 0 & 0 & 0 & 0 & 25.51 & 0 & 0 & 0 & 16.7 \\
\hline
\end{tabular}

Table 4: Elements Weight \% of three locations at Site B (Okhla barrage).

\begin{tabular}{|c|c|c|c|c|c|c|c|c|c|}
\hline \multirow[t]{3}{*}{ Elements } & \multicolumn{3}{|c|}{ Depths at Location 4} & \multicolumn{3}{|c|}{ Depths at Location 5} & \multicolumn{3}{|c|}{ Depths at Location 6} \\
\hline & $0-2 \mathrm{~cm}$ & $30-32 \mathrm{~cm}$ & $76-98 \mathrm{~cm}$ & $0-2 \mathrm{~cm}$ & $30-32 \mathrm{~cm}$ & $67-69 \mathrm{~cm}$ & $0-2 \mathrm{~cm}$ & $26-28 \mathrm{~cm}$ & $62-64 \mathrm{~cm}$ \\
\hline & \multicolumn{9}{|c|}{ Weight $\%$} \\
\hline Oxygen $(\mathrm{O})$ & 34.54 & 49.54 & 0 & 32.6 & 0 & 48.98 & 64.86 & 57.94 & 37.24 \\
\hline Silicon $(\mathrm{Si})$ & 0 & 0 & 38.85 & 29.16 & 32.5 & 0 & 0 & 0 & 29.43 \\
\hline Niobium (Nb) & 0 & 0 & 0 & 0 & 0 & 0 & 0 & 0 & 0 \\
\hline Aluminium (Al) & 0 & 0 & 0 & 0 & 13.24 & 0 & 0 & 0 & 18.67 \\
\hline
\end{tabular}


were the main elements found in the analysis. $\mathrm{Si}$ and $\mathrm{O}$ were present in major quantities in almost all the samples while $\mathrm{Nb}$ was recorded in very less amount in the sample taken from the surface $(0-2 \mathrm{~cm})$ of location 1 of Site A (Palla). Al was recorded from location 5 and 6 of Site B at the depth of $30-32 \mathrm{~cm}$ and $62-64 \mathrm{~cm}$. Elemental weight percentage and atomic percentage distribution in all the soil samples and the various depths on which samples were taken have been elucidated in Tables 1-4, while SEM images showing soil particles and EDAX spectrum representing all observed elements are shown in Figs. 2-7 and Figs. 8-25 respectively [Gold $(\mathrm{Au})$ was also shown in graphs because soil samples
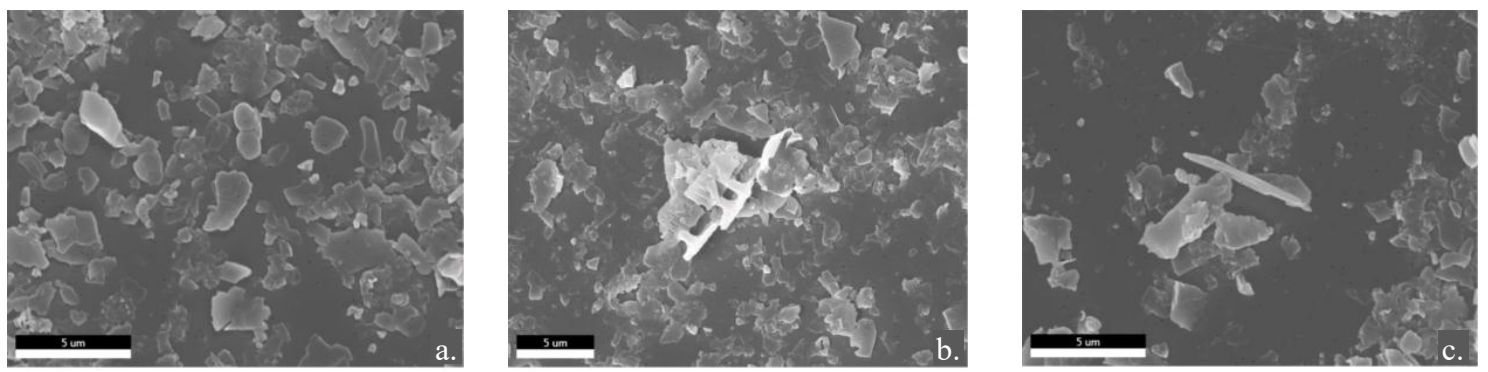

Fig. 2: a,b,c. SEM images showing soil particles of different depths 0-2 cm(a), 30-32 cm(b), 78-80 cm(c) at Location 1 at Site A (Palla Village).
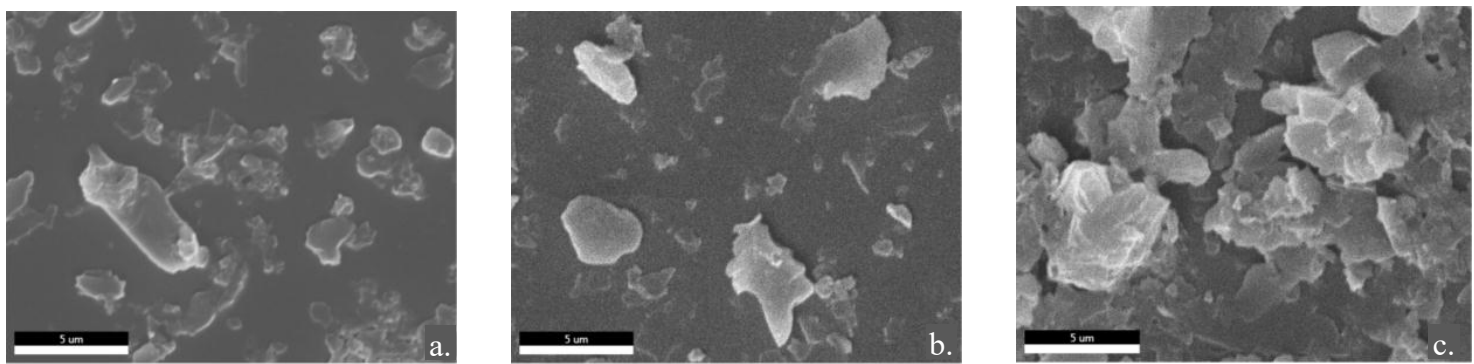

Fig. 3: a,b,c. SEM images showing soil particles of different depths 0-2 cm (a), 30-32 cm (b), 74-76 cm (c) of Location 2 at Site A (Palla Village).
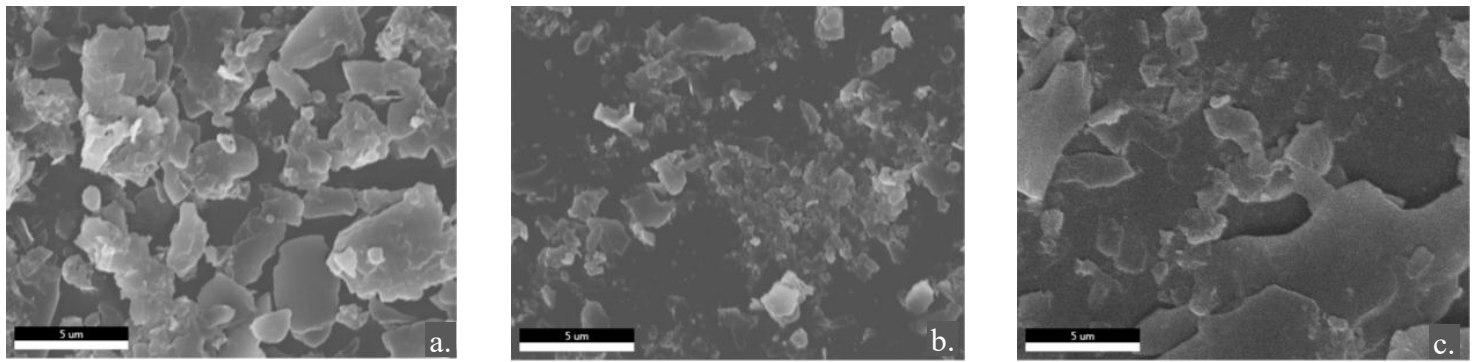

Fig. 4: a,b,c. SEM images showing soil particles of different depths 0-2 cm (a), 26-28 cm (b), 59-61 cm(c) of Location 3 at Site A (Palla Village).
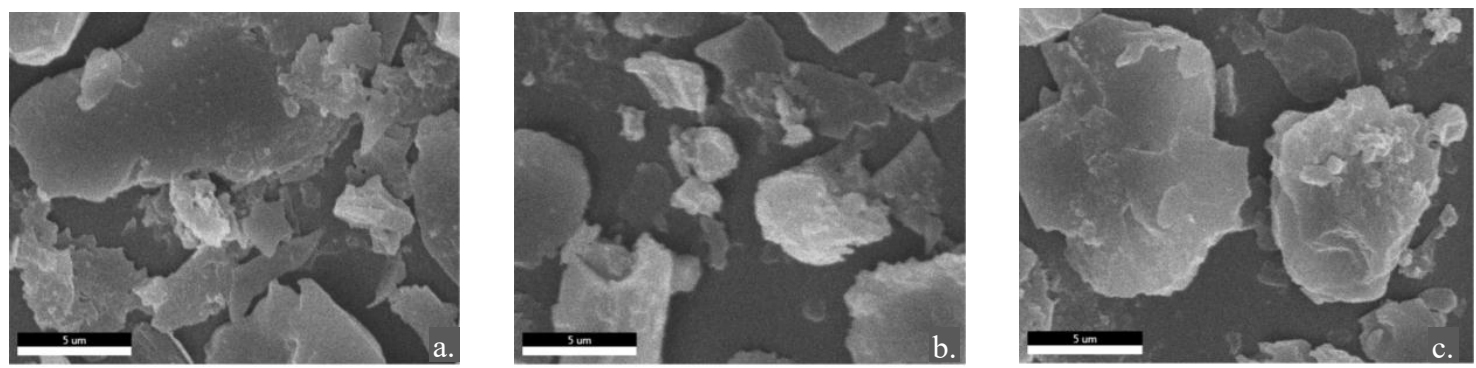

Fig. 5: a,b,c. SEM images showing soil particles of different depths 0-2 cm (a), 30-32 cm (b) and 76-98 cm (c) at Location 1 at Site B (Okhla barrage). 

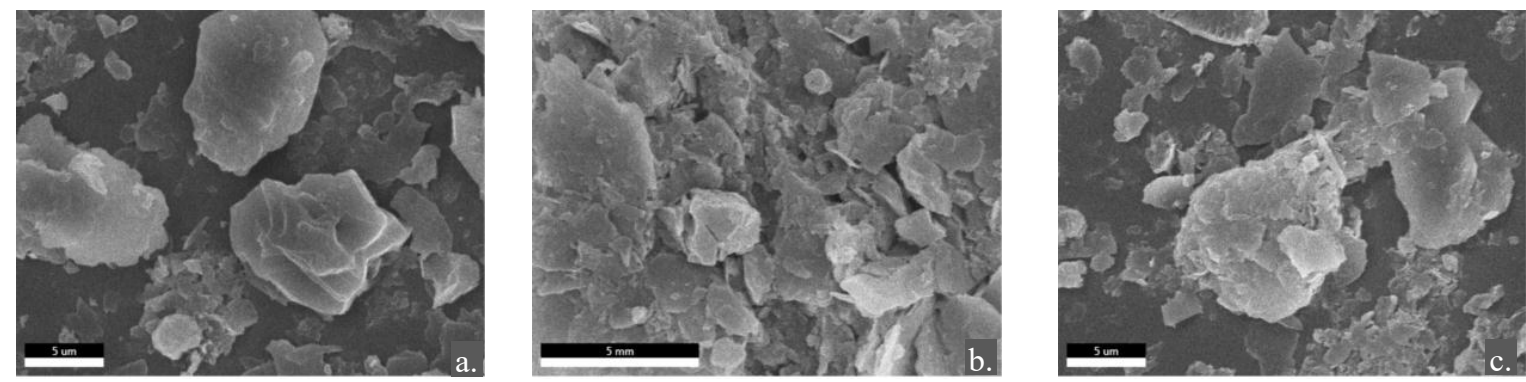

Fig. 6: a,b,c. SEM images showing soil particles of different depths 0-2 cm (a), 30-32 cm (b) and 67-69 cm (c) at Location 2 at Site B (Okhla barrage).
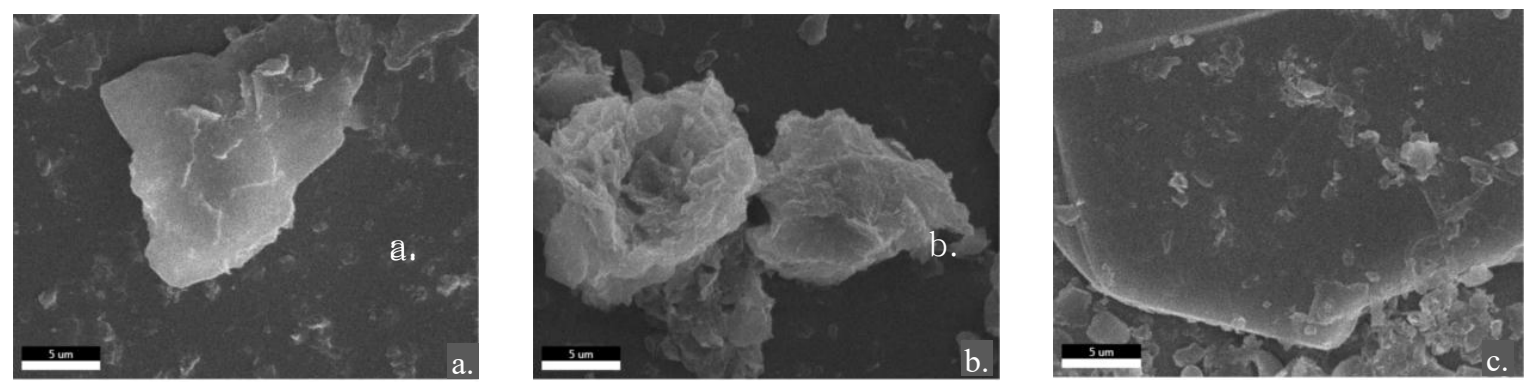

Fig. 7: a,b,c, SEM images showing soil particles of different depths 0-2 cm (a), 26-28 cm (b) and 62-64 cm (c) at Location 3 at Site B (Okhla barrage).

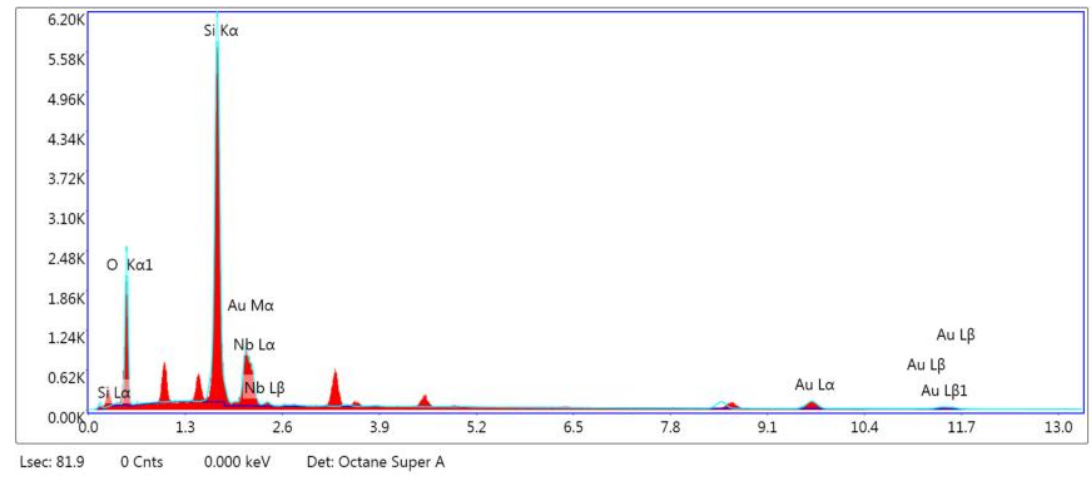

Fig. 8: EDAX spectrum of Location 1 (Depth 0-2 cm) at Site A (Palla Village).

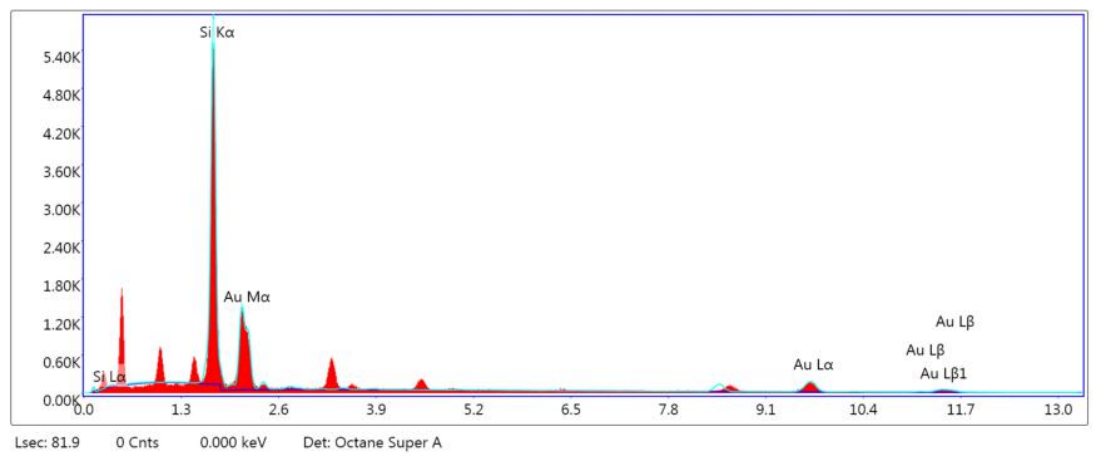

Fig. 9: EDAX spectrum of Location 1 (Depth $30-32 \mathrm{~cm}$ ) at Site A (Palla Village). 


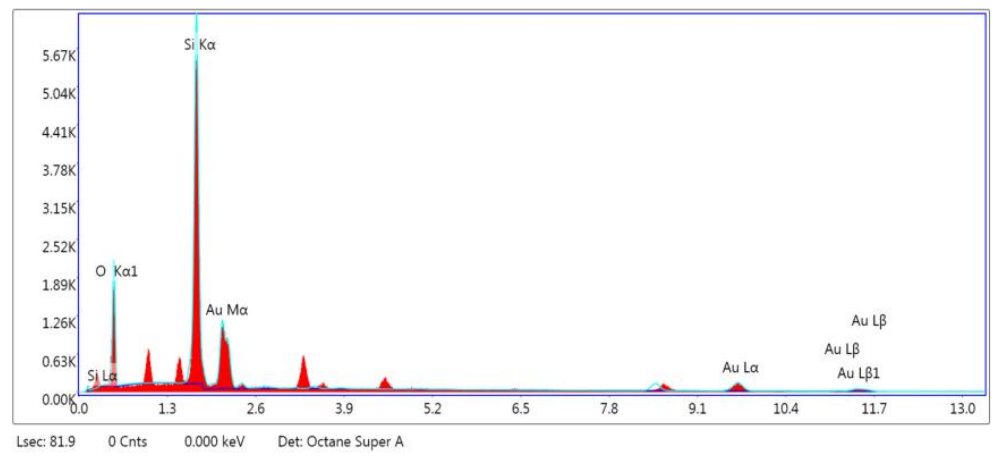

Fig. 10: EDAX spectrum of Location 1 (Depth $80-82 \mathrm{~cm}$ ) at Site A (Palla Village).

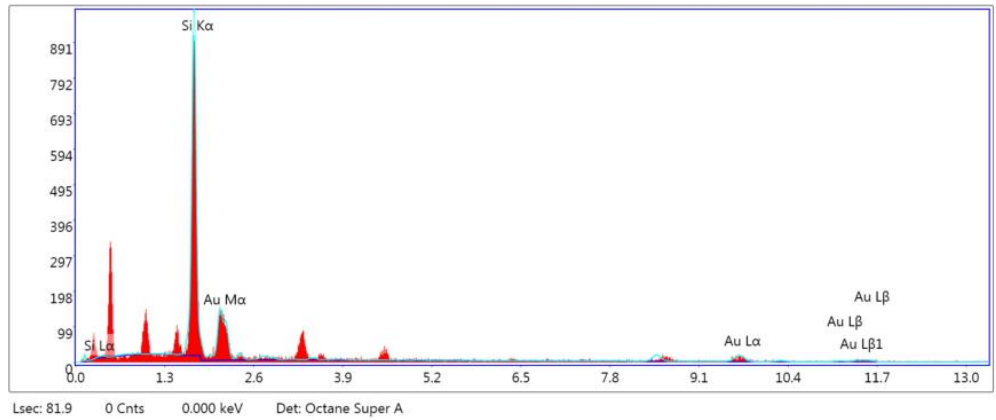

Fig. 11: EDAX spectrum of Location 2 (Depth 0-2 cm) at Site A (Palla Village).

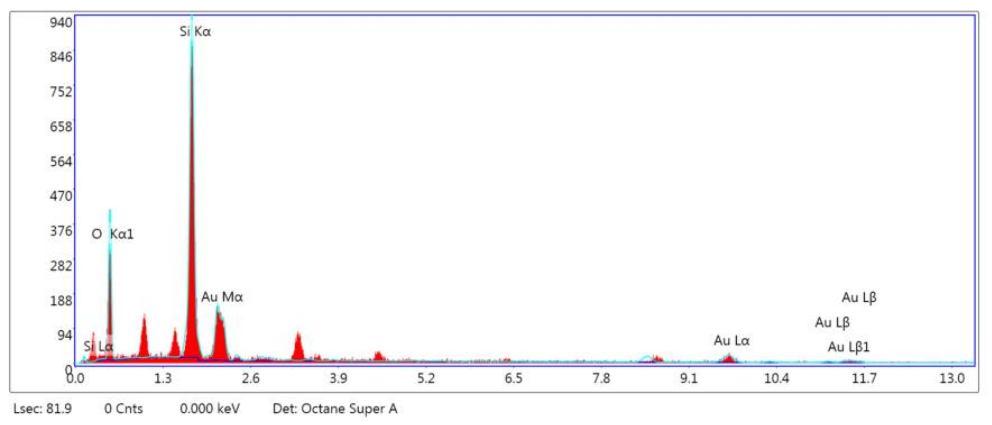

Fig. 12: EDAX spectrum of Location 2 (Depth 30-32 cm) at Site A (Palla Village).

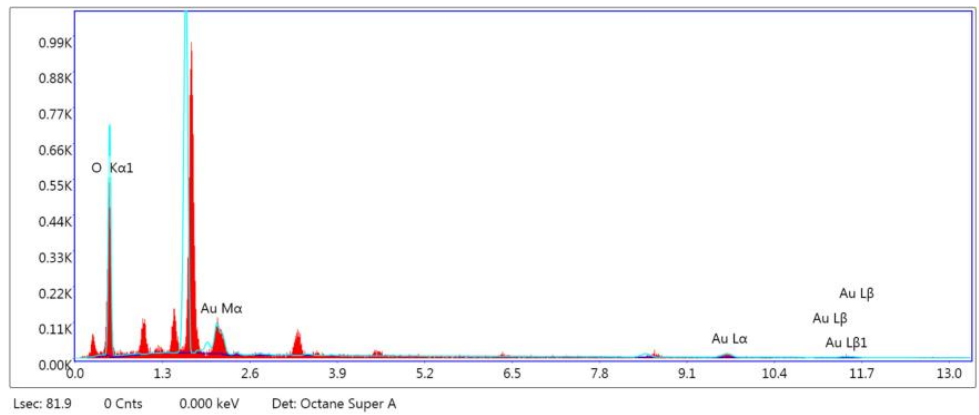

Fig. 13: EDAX spectrum of Location 2 (Depth 74-76 cm) at Site A (Palla Village). 


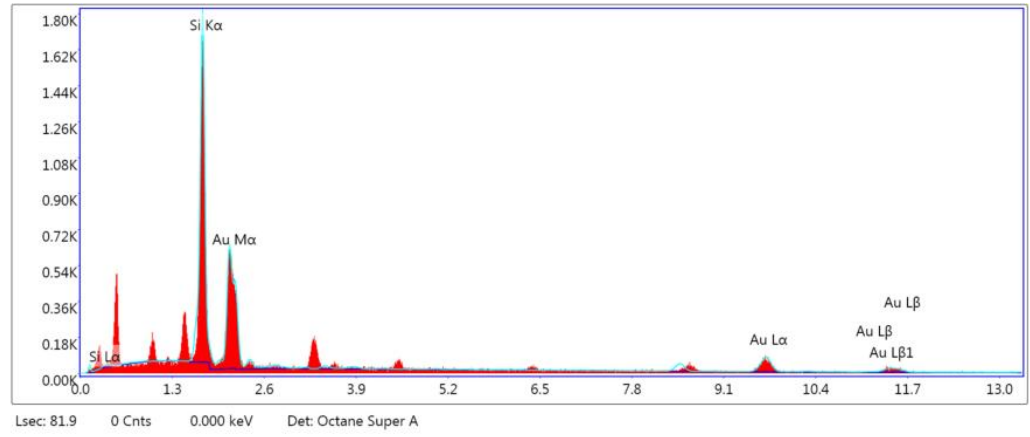

Fig. 14: EDAX spectrum of Location 3 (Depth 0-2 cm) at Site A (Palla Village).

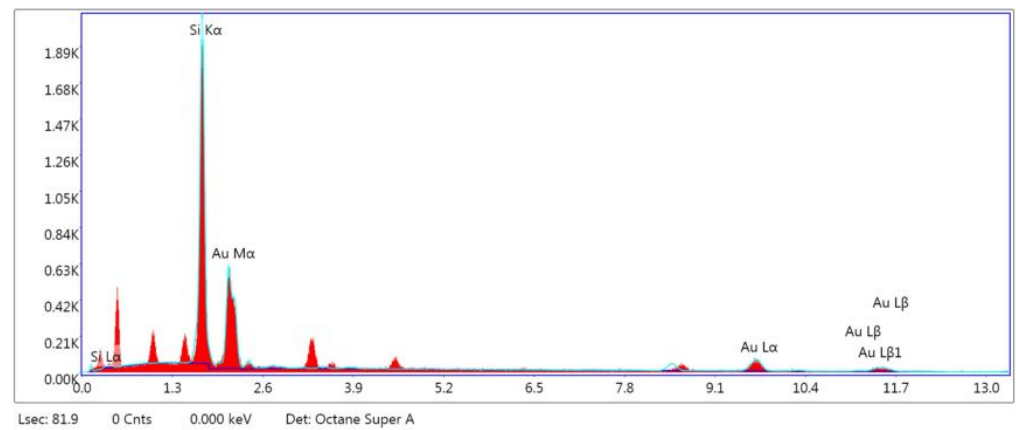

Fig. 15: EDAX spectrum of Location 3 (Depth 26-28 cm) at Site A (Palla Village).

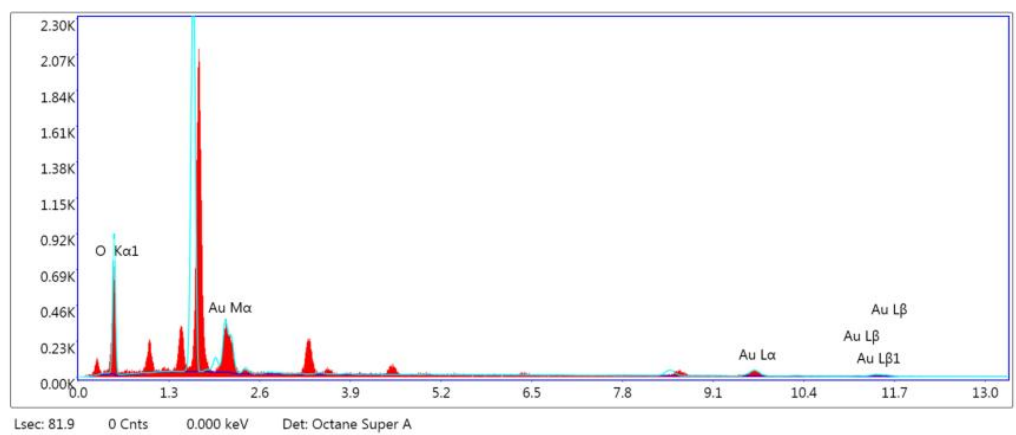

Fig. 16: EDAX spectrum of Location 3 (Depth 59-61 cm) at Site A (Palla Village).

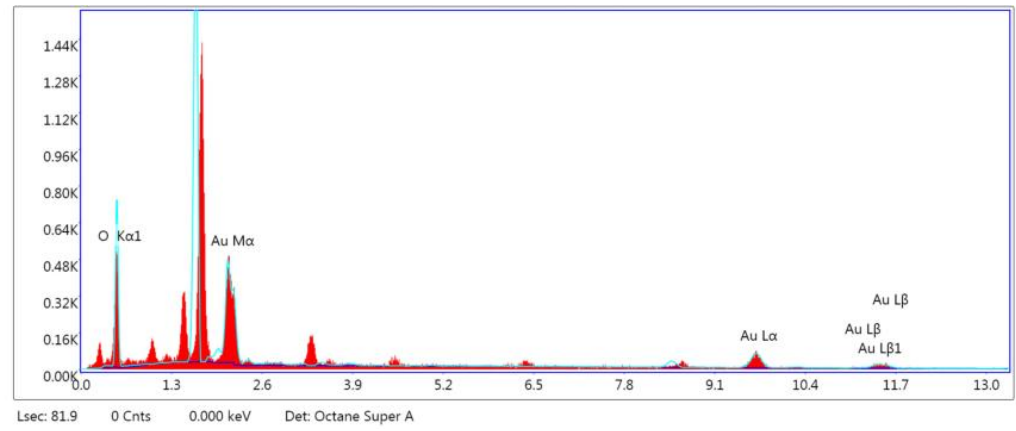

Fig. 17: EDAX spectrum of Location 1 (Depth 0-2 cm) at Site B (Okhla barrage). 


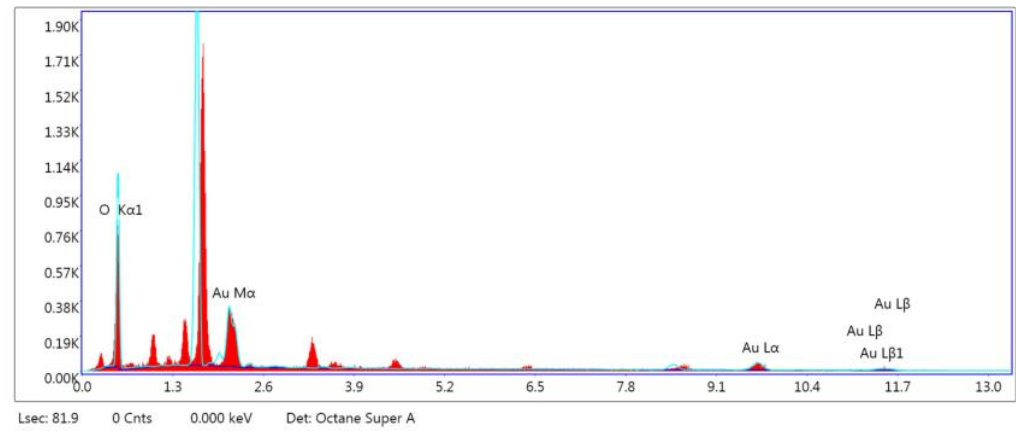

Fig. 18: EDAX spectrum of Location 1 (Depth 30-32 cm) at Site B (Okhla barrage).

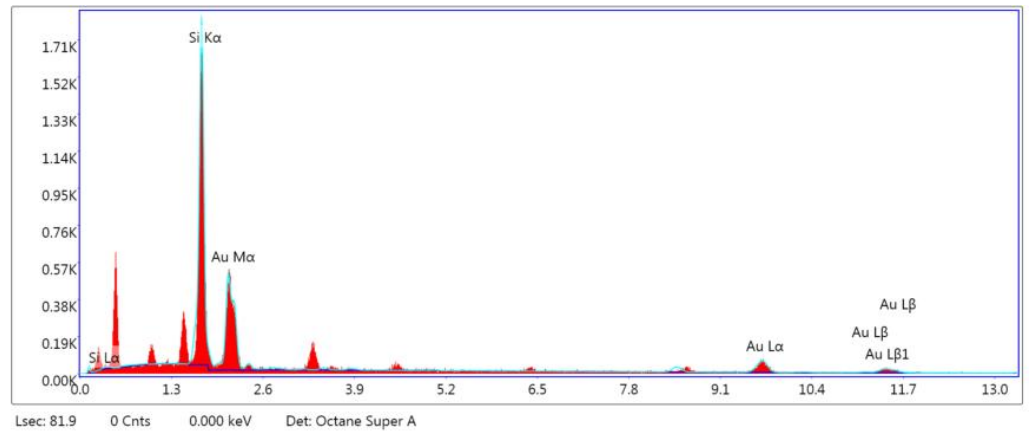

Fig. 19: EDAX spectrum of Location 1 (Depth 76-98 cm) at Site B (Okhla barrage).

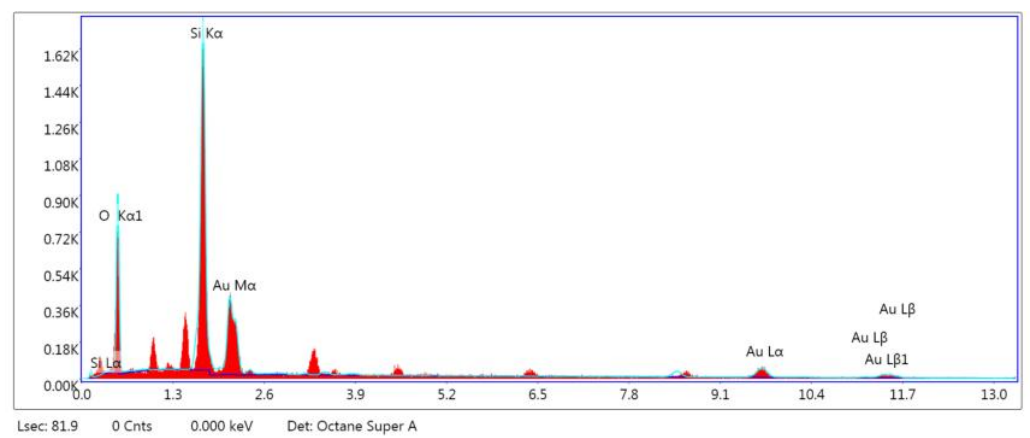

Fig. 20: EDAX spectrum of Location 2 (Depth 0-2 cm) at Site B (Okhla barrage).

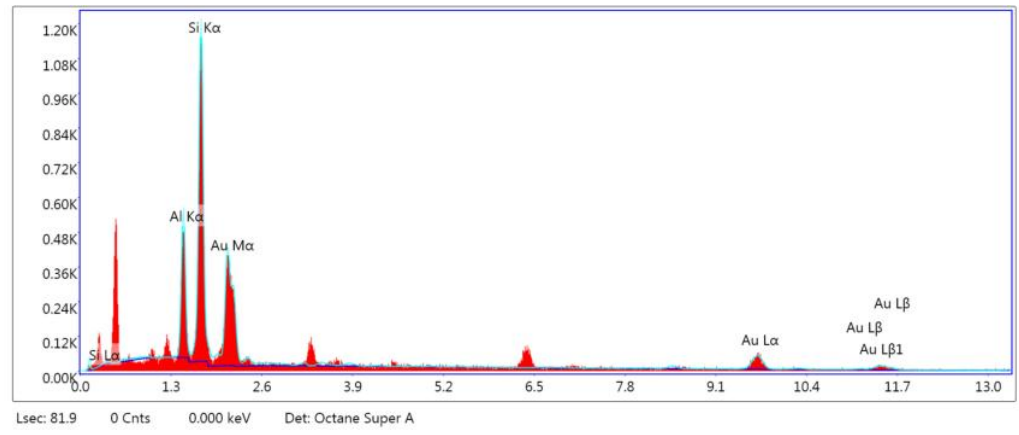

Fig. 21: EDAX spectrum of Location 2 (Depth 30-32 cm) at Site B (Okhla barrage). 


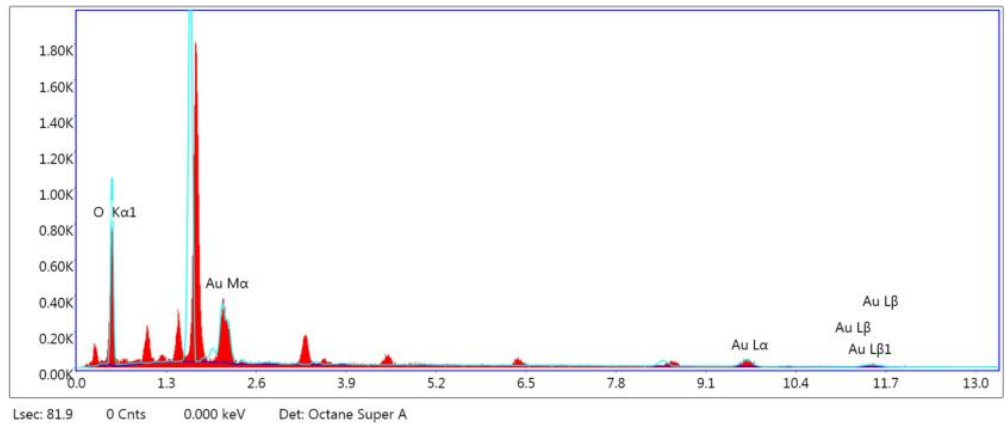

Fig. 22: EDAX spectrum of Location 2 (Depth 67-69 cm) at Site B (Okhla barrage).

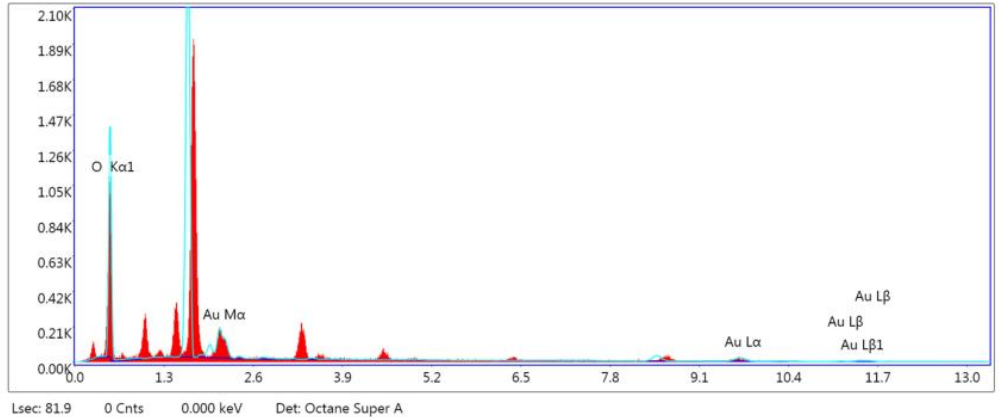

Fig. 23: EDAX spectrum of Location 3 (Depth 0-2 cm) at Site B (Okhla barrage).

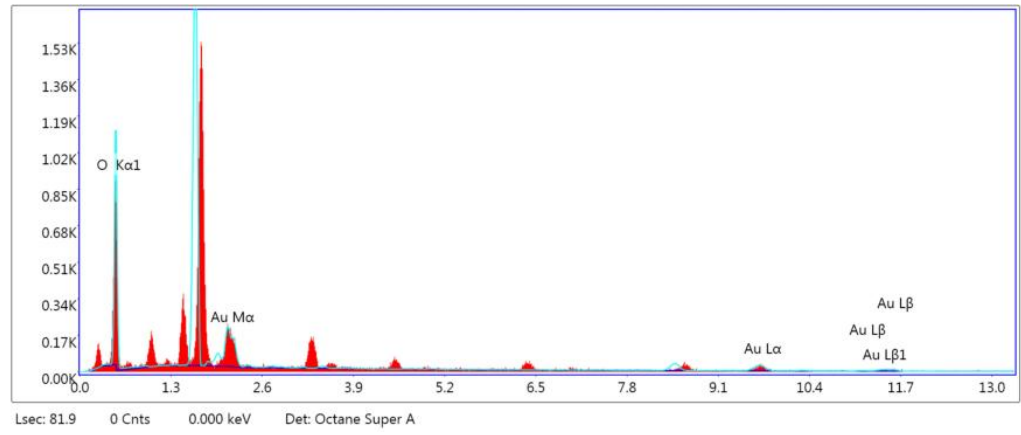

Fig. 24: EDAX spectrum of Location 3 (Depth 26-28 cm) at Site B (Okhla barrage).

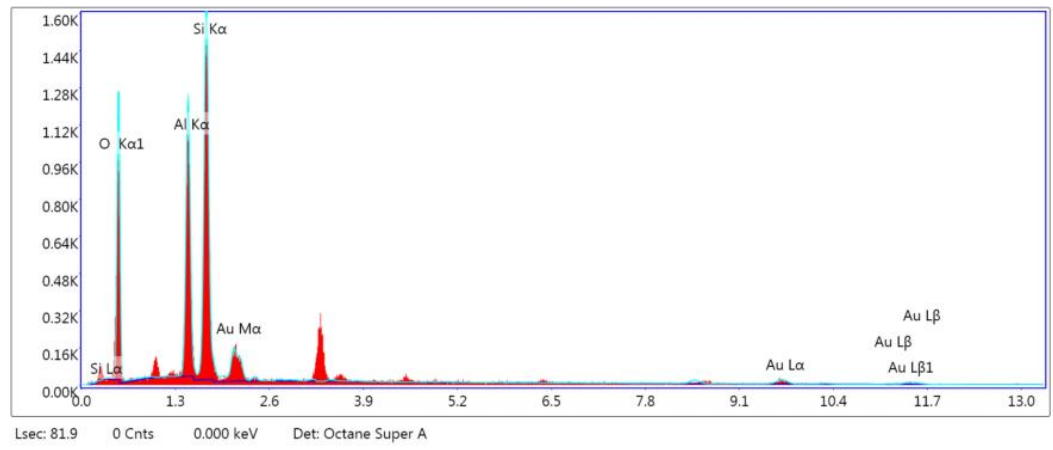

Fig. 25: EDAX spectrum of Location 3 (Depth 62-64 cm) at Site B (Okhla barrage). 
were plated with gold to observe diatoms, therefore, Au value has been discarded in the present study].

Isotopic composition of silicon in river sediments and its relation to climate was explained by Bayon et al. (2018). Distribution and retention of silicon in river beds and its effects on biogeochemical nature and aquatic food webs in coastal environments were discussed by Humborg et al. (2000), while the distribution of biogenic silica in sediments of the Yellow River was discussed by Yang et al. (2016). Mil-Homens et al. (2013) has talked about the occurrence of silicon as aluminosilicates in the sediments of Minho River, Spain. In the present study, the spatial distribution pattern of $\mathrm{Si}$ in different soil samples does not show any specific trend. Silicon affects the uptake and accumulation of different plant nutrients and most of the silicon is locked up in intractable silicate minerals and only a much smaller fraction is available for plants (Struyf et al. 2010). Silicon forms solid-phase phytoliths after absorbed in plants and with the deterioration of dead plant material these are recycled to the soil solution which may again be taken up by plants (Carey \& Fulweiler 2012). Hydrogen bound Si-organic complexes are often found in plant tissues (Carlisle et al. 1977) which permeates the walls of vessels and epidermis and reduces fungal infections and water transpiration by strengthening the plant tissues (Kaufmian et al. 1969). It also associates with cell wall components like lignins, polysaccharides, and proteins (Perry \& Lu 1992). Silicon affects the uptake, distribution and functionality of several mineral nutrients like nitrogen $(\mathrm{N})$, phosphorus $(\mathrm{P})$, potassium $(\mathrm{K})$, magnesium $(\mathrm{Mg})$ and calcium (Ca) (Wallace 1989, Miyake 1993, Brackhage et al. 2013, Neu et al. 2016, Sattar et al. 2016, Kostic et al. 2017) and strongly influence the uptake of boron (B), iron (Fe), zinc (Zn) and manganese (Mn) (Nable et al. 1990, Bityutskii et al. 2014). Soil concentrations of oxygen in solution are comparatively lesser than in the soil atmosphere which is used by aerobic microorganisms as a terminal electron acceptor for the period of degradation of organic compounds and xenobiotics and percentage volume basis of oxygen varies in the atmosphere, well-aerated soil surface and fine clay or saturated soil (Pepper \& Gerba 2019). Yamada et al. (2012) explained Dissolved Oxygen concentration in sediments of downstream of rivers in Lake Biwa in Japan. Similar studies on Dissolved Oxygen and Nutrient Fluxes across the Sediment-Water Interface of the Neckar River in Germany was performed by Haag et al. (2006). Concept of sediment oxygen demand (SOD) and the importance of oxygen was discussed by Belo (2008) in Pasing River.

Rock-forming minerals such as sphene, cassiterite rutile and biotite contain trace levels of Niobium and it shows a strong correlation with Ti, Ta, Th, U, Zr, Rb, Ga, Fe, V, Y and with some heavy Rare Earth Elements like Dy, Ho, Er, $\mathrm{Tm}$ and $\mathrm{Yb}$ while has a good negative correlation with $\mathrm{CaO}$ and forms some relatively rare, but economically significant minerals (Forges Geochemical Atlas of Europe). Production of steel, nuclear fuel and welding practice are some main human activities which lead Niobium in the environment (Reimann \& De Caritat 1998). It also has some industrial significance like manufacture cutting tools, pipelines and super magnets. It is considered non-essential and very less is known about its toxicity but its existence is not denied in living organisms and stream sediment. Astrom et al. (2008) did extensive studies on 807 streams spread over 26 countries in Europe for necessary statistics on the abundance, movement and transportation of Niobium in sediments of boreal stream water. Borghesi et al. (2015) studied the geochemical classification of surface sediments from wetlands around the Po river delta in Italy and suggested that organic matter in these wetlands can influence Niobium sediments. Periodic variations occurring in water quality in streams and rivers were demonstrated by Henriksen et al. (1984). In water bodies, Al can be added by industrial sources which are lethal for aquatic fauna (Hunter et al. 1980). The acidification caused by $\mathrm{Al}$ in water streams has generally been a reason for declining numbers of benthic and planktonic invertebrates (Okland \& Okland 1986, Haines 1981). The biological significance of Al toxicity on freshwater invertebrates was revealed by Herrmann (1987) and on fish by Driscoll et al. (1982). Horst et al. (1982) found aluminium traces in the mucilage layer on the root tips and the cell wall pectins while only a small extent is translocated to shoots. Physiological and biochemical implications of AI studies have been reported on humans as well as animals (Siegel 1985, Trapp 1986).

The shape, size and chemical constituents of soil reserves are vastly variable (Takahashi et al. 2001). SEM images revealed the irregular, elliptical, platy and spongy structures of soil particles in almost all the samples. Similar results and such inhomogeneous nature of the soil was reported by Sharma et al. (2016) in Hasdeo river basin in Chhattisgarh and by Thambavani \& Kavitha (2014) in Suruli river, Karnataka in India. Soils were sandy as all the samples were taken from the river bed which is mainly constituted of alluvial deposits. Sajitha et al. (2017) also used SEM EDAX to analyze Mineralogical and Morphological Characterization of Coastal Soil Samples of Kanyakumari District. The colour of the soil was light greyish at the Site A while it was darker and blackish at Site B because of the accumulation of sewage pollutants from nearby drains.

Studies revealed that the type and concentration of elements vary at different depths of the river bed and there 
is no unique pattern of occurrence of elements along the gradients of the river bed. It can be explained by the fact that the river ecosystem is a very dynamic one and the alluvial deposition can be easily disturbed by the flow of water or floods. Though the percentage of $\mathrm{Si}$ and $\mathrm{O}$ was significantly distributed in all the sites, the occurrence of $\mathrm{Al}$ at Site B proves the heavy load of pollution in the area and the potential source of the $\mathrm{Al}$ contamination might be from industrial effluents. The occurrence of $\mathrm{Nb}$ at Site A could be because of depositions from weathered rocks as $\mathrm{Nb}$ is an important part of many forms of rocks.

\section{CONCLUSION}

The extent of pollution faced by the Yamuna is a severe threat to its identity as a river. The study reveals that Site A lacks any type of heavy pollutant while the occurrence of $\mathrm{Al}$ at Site B confirms the presence of pollutants. The concentration of elements keeps varying from the surface to the bottom of the river bed and they do not follow any particular pattern of concentration. The present study helps us to understand the elemental composition and morphology of soil grains in the river bed. This further enhances our knowledge about the complex nature of elements distribution along the depths of the river bed which can be used for conservation studies and protection of such a fragile wetland ecosystem of our rivers.

\section{ACKNOWLEDGEMENTS}

We would like to thank Dr Neel Ratan, Mr Jogender Singh, Mr Virender Kumar and Mr Lalit Yadav for their kind help in the collection of soil samples. A kind thanks are also due to Mr. Madan Mohan Sharma for his assistance during SEM-EDAX analysis at SAIF, AIIMS, Delhi.

\section{REFERENCES}

Astrom, M., Peltola P., Virtasalo, J., Kotilainen, A. and Salminen, R. 2008. Niobium in boreal stream waters and brackish-water sediments. Geochemistry Exploration Environment Analysis, 8: 139-148. 10.1144/1467-7873/07-155.

Bayon, G., Delvigne, C., Ponzevera, E., Borges, A. V., Darchambeau, F., De Deckker, P. and André, L. 2018. The silicon isotopic composition of fine-grained river sediments and its relation to climate and lithology. Geochimica et Cosmochimica Acta, 229: 147-161. 10.1016/j. gca.2018.03.015.

Belo, Lawrence 2008. Measurement of the Sediment Oxygen Demand in Selected Stations of the Pasig River Using a Bench-scale Benthic Respirometer. 10.13140/2.1.3159.1369.

Bityutskii, N., Pavlovic, J., Yakkonen, K., Maksimovi, V. and Nikolic, M. 2014. Contrasting effect of silicon on iron, zinc and manganese status and accumulation of metal-mobilizing compounds in micronutrientdeficient cucumber. Plant Physiology and Biochemistry, 74: 205-211.

Borghesi, F., Migani, F. and Dinelli, E. 2015. Geochemical characterization of surface sediments from the northern Adriatic wetlands around the Po river delta. Part I: Bulk composition and relation to local background. Journal of Geochemical Exploration, 156. 10.1016/j. gexplo.2015.05.003.

Brackhage, C., Schaller, J., Bäucker, E. and Dudel, E.G. 2013. Silicon availability affects the stoichiometry and content of calcium and micro nutrients in the leaves of common reed. Silicon, 5(3): 199-204.

Carey, J.C. and Fulweiler, R.W. 2012. The terrestrial silica pump. PLoS One, 7(12): e52932.

Carlisle, E.M., McKeague, J.A., Siever, R. Van and Soest, P.J. 1977. Silicon. In: Geochemistry and the Environment, Elsevier, Washington, DC, USA, Volume 2.

CPCB, 2006. Assessment and development of the river basin series, water quality status of Yamuna River 1999-2005. Eds Sengupta, B. Central Pollution Control Board, Delhi, India

Das, B. and Mondal, N. K. 2011. Calcareous soil as a new adsorbent to remove lead from aqueous solution: equilibrium, kinetic and thermodynamic study. Universal Journal of Environmental Health and Biology, 1(4): 515-530.

Driscoll, C.T., Baker, J.P., Bisogni, J.J.Jr. and Schofield, C.L. 1982. Effects of aluminum speciation on fish in dilute acidified waters. Nature, 284: 161-164.

Forges Geochemical Atlas of Europe. Website address:weppi.gtk. fi $>$ publ $>$ foregsatlas $>$ text $>\mathrm{Nb}$

Haag, I., Schmid, G. and Westrich, B. 2006. Dissolved oxygen and nutrient fluxes across the sediment-water interface of the Neckar river, Germany: in situ measurements and simulations. Water, Air \& Soil Pollution, Focus, 6(5-6): 413-422.

Haines, T. 1981. Acidic precipitation and its consequences for aquatic ecosystems: A review. Trans. Am. Fish. Soc., 110: 669-707.

Henriksen, A., Skogheim, O.K. and Rosseland, B.O. 1984. Episodic changes in $\mathrm{pH}$ and aluminium-speciation kill fish in a Norwegian salmon river. Vatten, 40: 255-260.

Herrmann, J. 1987. Aluminium impact on freshwater invertebrates at low pH: A review. In: Speciation of Metals in Water, Sediment and Soil Systems, 157-175. Springer, Berlin, Heidelberg.

Horst, W.J., Wagner, A. and Marschner, H. 1982. Mucilage protects root meristems from aluminium injury. Zeitschrift für Pflanzenphysiologie, 105(5): 435-444.

Humborg, C., Conley, D.J., Rahm, L., Wulff, F., Cociasu, A. and Ittekkot, V. 2000. Silicon retention in river basins: Far-reaching effects on biogeochemistry and aquatic food webs in coastal marine environments. AMBIO: A Journal of the Human Environment, 29(1): 45-50.

Hunter, J.B., Ross, S.L. and Tarmahill, J. 1980. Aluminium pollution and fish toxicity. Water Pollut. Contr., 79: 413-420.

Kaufmian, P.B., Bigelow, W.C., Petering, L.B. and Drogosz, F.B. 1969. Silica in developing epidermal cells of Avena internodes. Science, 166: 1015-1017.

Kostic, L., Nikolic, N., Bosnic, D., Samardzic, J. and Nikolic, M. 2017. Silicon increases phosphorus $(\mathrm{P})$ uptake by wheat under low $\mathrm{P}$ acid soil conditions. Plant Soil, 419: 447-455.

Miyake, Y. 1993. Silica in soil and plants. Sci. Rep. Fac. Agric., 81: 61-79.

Mil-Homens, M., Costa, A.M., Fonseca, S., Trancoso, M.A., Lopes, C., Serrano, R. and Sousa, R. 2013. Characterization of heavy-metal contamination in surface sediments of the Minho River Estuary by way of factor analysis. Archives of Environmental Contamination and Toxicology, 64(4): 617-631.

Nable, R.O., Lance, R.C.M. and Cartweight, B. 1990. Uptake of boron and silicon by barley genotypes with differing susceptibilities to boron toxicity. Ann. Bot. Rev., 66: 83-90.

Neu, S., Schaller, J. and Dudel, G.D. 2016. Silicon availability modifies nutrient use efficiency and content, C:N:P stoichiometry, and productivity of winter wheat (Triticum aestivum L.). Sci. Rep., 7: 1-8.

Okland, J. and Okland, K.A. 1986. The effects of acid deposition on benthic animals in lakes and streams. Experientia, 42: 471- 486. 
Pepper, I.L. and Gerba, C.P. 2019. Environmental and Pollution Science. Elsevier.

Perry, C.C. and Lu, Y. 1992. Preparation of silica from silicon complexes: Role of cellulose in polymerisation and aggregation control. J. Chem. Soc. Faraday Trans., 88: 2915-2921.

Reimann, C. and De Caritat, P. 1998. Chemical elements in the environment: Factsheets for the geochemist and environmental scientist. Springer Science \& Business Media. 398 pp. Berlin, Heidelberg, New York, London, Paris, Tokyo, Hong Kong, Springer-Verlag.

Sajitha, S.S., Metilda, P. and Jenin, G.A. 2017. Morphological and mineralogical characterization of coastal soil samples of Kanyakumari District by FT-IR, XRD, SEM/EDAX. International Journal of Scientific Research and Management (IJSRM), 5(10): 7163-7171. 10.18535/ijsrm/v5i10.01.

Sattar, A., Cheema, M.A., Ali, H., Sher, A., Ijaz, M., Hussain, M., Hassan, W. and Abbas, T. 2016. Silicon mediates the changes in water relations, photosynthetic pigments, enzymatic antioxidants activity and nutrient uptake in maize seedling under salt stress. Grassl. Sci., 62: 262-269.

Sharma, R., Patel, K.S., Lata, L. and Milosh, H. 2016. Characterization of urban soil with SEM-EDX. American Journal of Analytical Chemistry, 7(10): 724-735. 10.4236/ajac.2016.710065.

Siegel, N. 1985. Aluminum interaction with biomolecules: The molecular basis for aluminium toxicity. Am. J. Kidney Dis., 6: 353-357.
Struyf, E., Smis, A., Van Damme, S., Garnier, J., Govers, G., Van Wesemael, B., Conley, D.J., Batelaan, O., Frot, E., Clymans, W. and Vandevenne, F. 2010. Historical land use change has lowered terrestrial silica mobilization. Nat. Commun., 1: 129.

Takahashi, T., Dahlgren, R.A., Theng, B.K.G., Whitton, J.S. and Soma, M. 2001. Potassium-selective, halloysite-rich soils formed in volcanic materials from Northern California. Soil Science Society of America Journal, 65: 516. http://dx.doi.org/10.2136/sssaj2001.652516x.

Tan, K.H. 2005. Soil Sampling, Preparation and Analysis. 2nd Edition, CRC Press, Boca Raton.

Thambavani, S. and Kavitha, B. 2014. Mineralogical characterization of river bed soil from Tamilnadu by FT-IR, XRD and SEM/ EDAX. International Journal of Advanced Research, 2: 656-659.

Trapp, G.A. 1986. Interactions of aluminum with co-factors, enzymes, and other proteins. Kidney Int., 29, Suppl.,18: S12-S16.

Wallace, A. 1989. Relationships among nitrogen, silicon, and heavy metal uptake. Soil Sci., 147: 457-460.

Yamada, Y., Mito, Y., Igeta, A. and Wada, E. 2012. Dissolved oxygen concentration in river sediment of the Lake Biwa tributaries, Japan. Limnology, 13: 149-154. https://doi.org/10.1007/s10201-011-0348-2.

Yang, X.H., Yang, H.W., Li, W.J. and Li, P. 2016. Distribution of biogenic silica in sediments of the Yellow River (Upper and Middle Reaches). Chemical Engineering Transactions, 55: 361-366. 